\title{
Godforsakenness: Is Christian Unbelief Possible? Yuliia Vintoniv
}

\begin{abstract}
:
The article is dedicated to the phenomenon of Godforsakenness viewed from philosophical and theological perspectives. The article presents the conception of the experience of Godforsakenness as a key element in finding spiritual reconciliation. Attention is focused on the fact that belief is impossible without (the despair of) Godforsakenness, the collapse of meaning, and the cry to God for help. Having compared the thoughts of A. Camus and C. S. Lewis, we will argue that the suffering of a human being appears in the centre of comprehension for both. The combination of critical positions of Albert Camus and C. S. Lewis provides the ground for asserting that both theology and philosophy, when it comes to the experience of Godforsakenness, mean the same thing but conceptualise it differently. Reflections pivot around the fact that every person is constantly in search of God, and that most often this path is a sinuous curve: from unbelief to belief, etc. We call these transitions within the state of Godforsakenness the experience of being 'without God'. Awareness of this makes it possible to regard atheism not only as a secular phenomenon but also as a theological problem that signals a disturbed balance in the faith in its quest for the living God, rather than for attractive theological formulas.
\end{abstract}

Keywords: Godforsakenness, kenosis, Crucifixion, belief and unbelief, Albert Camus, C. S. Lewis.

\section{Introduction}

Fergus Kerr called our era the era of Godforsakenness. It is characterised by despair, crisis, murder, hatred, irresponsibility, indifference, and loneliness. ${ }^{1}$ It has inherited the mutilated humanity which had been affected by two world wars and revolution, the 'killing of God' and party atheism, rationalism and technology. Gabriel Vahanian says that the main problem with post-Christianity is the loss of a sense of sacredness, ${ }^{2}$ a doubt in the fact that we each have dignity and value before the eyes of God. But in the darkness of Godforsakenness, miraculously, many people also managed to find God. In 1944, a Greek-Catholic priest, Omelyan Kovch, was executed in the Maidanek concentration camp. In his last letter from the concentration camp to his family, he wrote: 'Thank God for His kindness to me. Apart from Heaven, this is the only place I would like

1 Cf. Fergus KERR, Theology in a Godforsaken Epoch, New Blackfriars 543/1965, pp. 665-672.

2 Cf. Gabriel VAHANIAN, The Death Of God The Culture Of Our Post Christian Era, New York: George Braziller, 1961, pp. 148-149. 
to be. ${ }^{3}$ Almost half a century later, Igor Kozlovsky, coming out of DPR captivity, ${ }^{4}$ said: 'Is God at war? Is God there in the basements where the human spirit is tested? We can claim that He is only after going through this. I am the eternal debtor of love. ${ }^{.5}$ In order to understand the meaning and purpose of these trials, it is necessary to understand the meaning of this despair, for it too can be filled with the energy of holiness. ${ }^{6}$ Godforsakenness can be the place where we can meet God. In this article, we propose to consider the dualism of belief and unbelief, not as a confrontation, but as two sides of the same experience. Based on the doctrine of the Godforsakenness of Christ, we will demonstrate that the experience of the Godforsakenness of God is a crucial part of the soteriological dimension. The article does not purport to exhaustively cover the problem of belief and unbelief. The focus of the study is a philosophical and theological understanding of belief and unbelief through the experience of Godforsakenness in the writings of Albert Camus and Clive Staples Lewis.

\section{Godforsakenness: Is Belief in God Axiomatic?}

At the beginning of the twenty-first century, Charles Taylor voiced a very simple question: How is it to live as a believer or as a non-believer? ${ }^{7}$ In his understanding, the secular era not only divided people into believers and atheists, as in the parable about goats and sheep (Matt 25:31-46); but it also produced a hybrid, equivalent of faith, which relies not on facts but on experience. For believers it is an experience of communion with God, and for non-believers it is an experience of 'the silence of God', which is to say, His absence. Experience itself can speak of both the presence and the absence of God, but only 'here and now', and not in general. Moreover, the absence of God or Godforsakenness is not some kind of taboo within the Christian realm: we have seen it experienced in the life of John of the Cross, Teresa of Avila, Therese of Lisieux, Simone Weil, and many others. In the end, even Christ shouted on the cross: 'My God, my God, why have you forsaken me?' (Matt 27:46; Mk 15:34).

Charles Taylor asserts that 'belief in God is no longer axiomatic. ${ }^{8}$ From the perspective of theological anthropology, this process began in the Garden of Eden. Judaism and Christianity look at the history of the fall of man as the source of the explanation for evil in the world, as well as the ability to choose to believe or not to believe in God. The Jewish-religious philosopher Pinchas Polonsky emphasises that the story of Adam and Eve tells us not only about the knowledge of good and evil. It is also about the inseparability of good and evil in the submission of man, which may mean that man does not have the ability to distinguish between good and evil, without going beyond himself. ${ }^{9}$ Christian tradition tells us the same and emphasises the rising of man to the greatness of God, like a set of 'stairs' that we ascend by cutting off our passions and sins. However, this

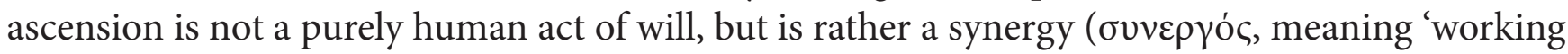

Blazhennyj svyashchennomuchenyk Omelyan Kovch [Blessed Holy Martyr Omelyan Kovch] Archive of the postulation centre UGKC, 3.

4 The Donetsk People's Republic (DPR) is a proto-state in the Donetsk Oblast of Ukraine recognised only by the partially recognised South Ossetia and Luhansk People's Republic.

5 (c) Igor KOZLOVSKY, Open lecture Svoboda i polon [Freedom and Captivity] (on-line), available from: https://zbruc.eu/ node/92129?fbclid=IwAR1IqbU2t5-m41XJJgCfM4sIxmLT-EsDS1SL92e4GSyxsX779XO29HKMiOE, updated $16^{\text {th }}$ September 2019. Igor Kozlovsky is Senior Researcher, Department of Religious Studies, Institute of Philosophy, named after G.S. Skovoroda of the National Academy of Sciences of Ukraine. On $27^{\text {th }}$ January 2016, he was captured by militants of the so-called 'Donetsk Peoples Republic' and was in captivity for almost 2 years (700 days) until $27^{\text {th }}$ December 2017.

6 Cf. Sofronyj SAKHAROV, Taynstvo khrystyanskoj zhyzny [The Sacrament of the Christian Life], Svyato-Troyczkaya Sergyeva Lavra, 2012, p. 35.

7 Cf. Charles TAYLOR, A Secular Age, The Belknap Press of Harvard University Press Cambridge, 2007, pp.4-5.

8 TAYLOR, A Secular Age, p. 4.

9 Cf. Pinchas POLONSKY, Biblejskaya dinamika sovremennyj kommentarij k Pyatiknizhiyu [Biblical Dynamics Contemporary Commentary on the Pentateuch], Kyiv: Duh i Litera, 2014, p. 147. 
together') of God and man. God brings man to himself through economy, the descending relation of God to man, the sign of which is the Incarnation of Christ. Therefore, when Christian theologians reflect about the human being, their starting point is always Christ who embodies God's original conception of man (1 Cor 15:45).

The Apostle Paul in his letter to the Hebrews says that we are in the person of Jesus Christ, that we have a high priest who 'has been tempted in every way, just as we are - yet he did not sin' (Heb 4:15). Therefore, Godforsakenness is not a sin, it is an experience of the absence of God, it is an experience of fierce anxiety for God. We see this in the trial of the Godforsakenness of Jesus Christ on the cross who goes to the very end of His kenosis ( tion of Christ. If kenosis explains how Christ could be God, the second hypostasis of the Trinity, and at the same time human, then economy (oikovouia) explains how Christ was able to pass the experience of Godforsakenness. ${ }^{10}$ The forsakenness of the God-Son is the highest expression of love for each person. It also gives eschatological hope in the perspective of the Resurrection.

The concept of Godforsakenness is synthetically inferred from the New Testament according to Matthew and Mark about the crucifixion of Christ: 'From noon until three in the afternoon darkness came over all the land. About three in the afternoon Jesus cried out in a loud voice, "Eli, Eli, lama sabachthani?" which means "My God, my God, why have you forsaken me?"' (Mt 27:46). The words spoken by Christ are from the twenty-second psalm, traditionally used by Jews to mourn suffering and death. All interpretations about why these words are exclaimed by Christ can be reduced to the one by the Apostle Paul in his words about the last Adam: 'For since death came through a man, the resurrection of the dead comes also through a man. For as in Adam all die, so in Christ, all will be made alive' (1 Cor 15:21-22). It would seem that even here there is a confrontation that Adam sinned, and Christ delivered from sin. But this is not the case - this opposition was united in Christ himself. Christ, as the last Adam, had to enter the experience of the first Adam, who fell, had to be expelled from paradise, had to depart from communication with God face to face. It was the time when God was hidden and communication between man and God took place indirectly: God comes in a burning bush (Ex 3:2), in a thick cloud (Ex 19:9), speaks through a storm (Job 38:1), etc. This is the greatest stumbling block for unbelievers, expressed in the words of the apostle Thomas: 'Unless I see I will not believe' (John 20:25), but it also remains the greatest internal conflict for believers because 'blessed are those who have not seen and yet have believed' (John 20:29). That's why the experience of Godforsakenness is the space where the incompatibility of faith and unbelief is combined. It is an experience that can be conveyed as the 'presence of absence' of God.

Experience of Godforsakenness also reminds us that God becomes absent or dead only in the person in whom he was present and living. This is exactly what atheism tries to express because one who does not have God cannot feel his absence. After all, Christ himself is the embodiment of this paradox: the God who incarnated and became man is also the fullness of being, which he expresses through the statement 'I am' in the Gospel of John: 'I am the bread of life' (6:35), 'I am the light of the world' (8:12), 'I am the gate' (10:9), 'I am the good shepherd' (10:11), 'I am the resurrection and the life' (11:25), 'I am the way and the truth and the life' (14:6), 'I am the true vine, and my Father is the gardener' (15:1), which all means 'I am everything. Godforsakenness is a constant state of crying out for God, by communication with Him, to which man has been called since the beginning of the world (Gen 1-2). Godforsakenness is an expression of the emptiness

10 Cf. Sergey BULGAKOV, Sofyologyya Smerty [Sophiology of Death], Vesnyk russkogo xrystyyanskogo dvyzhenyya Le messager Paris, New York, Moscow 4/1978, p. 26. 
that cannot be filled with anything other than God. As St Augustine writes, that God madest us for Thyself, and our heart is restless, until it reposes in Him. ${ }^{11}$ The intent of Godforsakenness is to express complaint to God, namely, He is the permanent recipient of this experience: crying out, complaint, anger, supplication, even denial of the existence of God.

While speaking about the experience of Godforsakenness one should note the following: firstly, this experience is inseparable from the human experience of life as well as the experience of pain, love, fear, or anything else that occurs in human life; secondly, as with any experience, it is subjective, but at the same time authentic and helps to reveal the whole range of similar religious experiences; thirdly, the experience of Godforsakenness is not equal to committing infidelity, but it is the experience of a hidden God, it is a mystery.

\section{Albert Camus and C. S. Lewis: In the Beginning There Was Darkness}

After the proclamation of the 'death of God' in the 1960s by the journal 'Time', Thomas Merton pointed out that the God whose live existence this famous periodical questioned was no God at all but was rather a caricature whose image had been corrupted over the centuries. ${ }^{12} \mathrm{He}$ is one of the few people in the Christian world who discerned behind the position of Albert Camus not just a rebel and atheist, but a prophet. Merton said that if Christians want to hear what the secular world really expects of them, they should invite Albert Camus to the dialogue, as the publishing house of Dominicans Le Cert did in France. ${ }^{13}$ But what can be in common between the Oxford professor and Christian apologist C. S. Lewis and the French-Algerian philosopher and rebel A. Camus?

In the twentieth century, when the world was divided by the Berlin Wall and the invisible wall of the Soviet Union's 'paradise', there were not many thinkers who dared to oppose the dichotomy of Nazism-Communism and at the same time take a critical Christian stance toward the 'dead God'. C. S. Lewis and A. Camus were in opposition to these ideas and opinions. They were not 'dedicated' scholars of morality or theology and philosophy, but they contributed the most to its formation. The key issues that unite Camus and Lewis are human suffering and the experience of Godforsakenness. The main question of Camus and Lewis's work was whether life is worth living. ${ }^{14}$ This question was pervasive in all spheres of life of these authors. Everyone was looking for an answer in their own way. The figure of Albert Camus is defined by two seemingly mutually-exclusive characteristics: the non-Christian with a 'conscience of the West', but not anti-Christian ${ }^{15}$ philosopher. Merton saw Camus as a post-Christian thinker 'who combined an obscure sense of certain Christian values the lucidity and solidarity of men in their struggle against evil with an accusatory, satirical analysis of the Christian establishment and the faithful. ${ }^{16}$ For Camus, the phenomenon of Godforsakenness is the fundamental basis of rebellion. In the essay The Rebel Camus tries to identify the main causes and mechanisms of rebellion, amongst which Godforsakenness is key. The philosopher writes that Christ came to solve two problems of mankind - evil and death, because there are all forms of rebellion, but instead, Christ falls into the despair of Godforsakenness:

The night on Golgotha is so important in human history only because in this darkness the deity, having

11 The Confessions of Augustine, Boston: Draper and Halliday, 1867, First book, I.

12 Cf. Ross LABRIE and Angus STUART, Thomas Merton: Monk on the Edge North Vancouver, 2012, p. 170.

13 Cf. Thomas MERTON, The Literary Essays, New Directions, 1985, p. 264.

14 Cf. Clyde S. KILBY, The Christian World of C. S. Lewis, Michigan: Grand Rapids, 1964, p. 183.

15 Cf. Thomas L. HANNA, Albert Camus and Christian Faith, The Journal of Religion 4/1956, pp. 224-225.

16 MERTON, The Literary..., p. 211. 
become disenfranchised and having lost its traditional privileges, experiences despair and, in addition, fear of death. This is how 'Lama sabachtani' and the terrible doubt of Christ, who was in agony, is explained. An agony would have been easy if he had the support of hope in eternity. For God to become a real man, he must feel despair. ${ }^{17}$

Camus thinks that despair and the feeling of forsakenness of the Father is a sign of the complete incarnation of Christ, of his true humanity. Camus argues that the denial of the Godforsakenness of Christ and, consequently, the solidarity of Christ with people who also experience Godforsakenness, is in fact the hidden modern Gnosticism that divides God and man. Camus denies the Old Testament view that the cause of suffering is sin, because Christ also suffered, and $\mathrm{He}$ is sinless, but Camus forgets that to suffer for mankind is a voluntary choice of Christ (cf. Luke 22: 3942,45-23:1). Nevertheless, Camus claims these thoughts of God's suffering unwittingly take away injustice from suffering. This was not Christ's purpose, but rather it was another interpretation of society, when the idea of suffering and rewards in eternity is a way of justifying social inequality. ${ }^{18}$ Suffering as a condition of salvation becomes another pseudo-religion, which in postmodern times turns into the idea of 'dead God', because even He cannot stop suffering. Therefore, the idea of rebellion becomes a necessity for the existence of man as Camus emphasises:

Since Christ had suffered this, and willingly, no suffering was no longer unfair, every pain was necessary. In a certain sense, the bitter intuition of Christianity and its legitimate pessimism as for the human heart, is that the generalised injustice is as satisfactory for the man as the total justice. Only the sacrifice of innocent God could justify the long and universal torture of innocence. Only God's suffering, and that of the most miserable, could alleviate the agony of men. If everything, without exception, from heaven to earth, is delivered to the pain, a strange happiness is then possible. ${ }^{19}$

Thus, the one important thing that we should learn from the experience of Godforsakenness is that, according to Camus, if we cannot understand the meaning of the suffering of Christ we will form our image of the God-Father as an 'evil Demiurge', an 'evil god who made his Son suffer'. Thomas Merton calls these considerations of Camus 'the theology of evil, ${ }^{20}$ mainly a caricature of God conceived in Camus through misreading St Augustine's theology of sin and grace when he was still a university student. Moreover, Camus observes that, based on the injustice of the universe of which God is supposedly guilty, mankind is trying to justify murder. If God does not exist or is evil, then any attempt by man to establish his own justice is only justified by the struggle against evil. Unfortunately, rebellion against injustice is still murder. Camus is also aware of this, so he involuntarily starts to protect the existence of a loving God necessarily required as a guarantor for the preservation of man.

While Camus chooses rebellion as the starting point for explaining Godforsakenness, C. S. Lewis chooses suffering. He speaks substantially on this in his work The Problem of Pain (1940), his first apological text. Lewis demonstrates in this book that the problem of Godforsakenness can be reduced either to the existence of an unfair God, or to the non-existence of God. His most popular thesis from this book is that God uses suffering as a megaphone into which God cries in order to

17 Albert CAMUS, L’homme Révolté, Paris: Gallimard, 1951, p. 41.

18 Cf. Niceta M. VARGAS, Word and Witness: an Introduction to the Gospel of John, Ateneo De Manila Univ. Press, 2014, pp. 285-303.

19 CAMUS, L'homme ..., p. 43.

20 Cf. MERTON, The Literary..., p. 263. 
lift the deaf world to its feet. ${ }^{21}$ John Beversluis calls this statement a 'shattering thesis' because it completely destroys the basic principle of true love - unconditionality. ${ }^{22}$ This is also completely contrary to Camus's view of the cause of suffering. If suffering is an instrument of God, it cannot be stopped and stopping it would be equal to injustice.

Lewis, like Camus, emphasises that the concepts of 'justice' and 'injustice' are false because they mean that each person proclaims what is good and evil just for them. Moreover, Lewis is convinced that the world is just and the proof of this is in the fact that at any stage of our existence we can rebel $^{23}$ and may choose to love 'the loving God more than our self or to love ourself more than God'. ${ }^{24}$ If Lewis perceives the freedom of choice as a gift, Camus locks himself in the struggle against suffering so much that he does not notice the beauty of that gift. Lewis wrote: 'Try to exclude the possibility of suffering which the order of nature and the existence of free-wills involves, and you find that you have excluded life itself'. ${ }^{25}$

But how then to integrate suffering into believing in a loving God? First, Lewis emphasises that suffering is not good in itself. ${ }^{26}$ Second, Lewis wrote that suffering destroys our self-sufficiency, and only then do we enter into the power of God, become united with Him, and He begins to act in us; it is a manifestation of human kenosis - to lay down arms, to acknowledge powerlessness, and to give God's place to God. And lastly, Lewis emphasises that Jesus Christ, the Son of God, is sinless, but He suffered for the sake of others, all of us. And if we want to follow Christ, it means that it is just to accept suffering for others and from others, to enter into the experience of suffering, Godforsakenness, and loneliness in Christ because He has already been there.

Twenty years after the publication of The Problem of Pain, Lewis wrote another book, or, rather, a journal of agony: A Grief Observed. If the first is rather a theoretical introduction to the problem of suffering, the second is a practical guide to experiencing personal grief. In it, Lewis takes the reader on a 'bereaved and as it were halved - journey on, through this Vale of Tears, alone. ${ }^{27}$ This book was first published under the pseudonym N. W. Clerk with the dedication to H. (Helen) - the second name of his wife, and only three years later, in 1964, the book came out under the name of Lewis. ${ }^{28}$ The reason for this was the atypical content of the book for a Christian apologist:

If God's goodness is inconsistent with hurting us, then either God is not good or there is no God: for in the only life we know He hurts us beyond our worst fears and beyond all we can imagine. If $\mathrm{He}$ is consistent with hurting us, then He may hurt us after death as unendurably as before it. Sometimes it is hard not to say, 'God forgive God.' Sometimes it is hard to say so much. But if our faith is true, He didn't. He crucified Him (...). No, my real fear is not of materialism. I am more afraid that we are really rats in a trap. Or, worse still, rats in a laboratory. Someone said, I believe, 'God always geometrises.' Supposing the truth were 'God always vivisects?' What reason have we, except our own desperate wishes, to believe that God is, by any standard we can conceive, 'good'? Doesn't all the prima facie evidence suggest exactly the opposite? What have we to set against it? We set Christ against it. But how if He were mistaken? His last words may have a perfectly clear meaning. He had found that the Being He called Father was horribly and infinitely different from what $\mathrm{He}$ had supposed. The trap, so long and carefully prepared and so subtly baited, was at last sprung, on the cross. ${ }^{29}$

21 Cf. C. S. LEWIS, The Problem of Pain, Samizdat University Press Québec, 2016, pp. 57-58.

22 Cf. John BEVERSLUIS, C. S. Lewis and the Search for Rational Religion, Grand Rapids, MI: Eerdmans, 1985, p. 114.

23 Cf. LEWIS, The Problem..., p. 9.

24 Ibid., p. 13.

25 Ibid., p. 16.

26 Ibid., p. 69

27 C. S. LEWIS and Giovanni CALABRIA, Letters: C. S. Lewis [and] Don Giovanni Calabria: a study in friendship, Servant Books 1988, pp. 106-107.

28 Calvin TRILLIN, Companionship in Grief: Love and Loss in the Memoirs of C. S. Lewis, University of Massachusetts Press, 2010 , p. 61.

29 C. S. LEWIS, A Grief Observed, Faber \& Faber, 1964, pp. 13-14. 
Certainly, these quotations show us only experiencing a huge and painful loss, where the feeling of Godforsakenness is quite natural: shock, denial, pain, anger, and acceptance. ${ }^{30}$ If the book The Problem of Pain was born due to an apologetic need to respond to the meaning of suffering in times of war, A GriefObserved is written as a chronicle of the experience of a personal inner war. Alister McGrath calls A Grief Observed a book without self-censorship which is Lewis's true feelings. Moreover, according to McGrath, it was this book in which Lewis allowed himself to deflect any expectations of friends and the public and to be honest. Thus, in order not to embarrass anyone, he published it under a pseudonym. ${ }^{31}$ No rational or orderly reasoning can match or surpass the grief itself. Lewis's faith crumbles. He experiences naked Godforsakenness. He demonstrates to us the Edenic archetype of Adam and Eve, who doubted the love of God and tasted the forbidden fruit to become like God (Gen 3:1-13). Lewis himself fell into the rationale trap he had formed many years before: 'If God were good, He would wish to make His creatures perfectly happy, and if God were almighty, He would be able to do what He wished. But the creatures are not happy. Therefore, God lacks either goodness, or power, or both. ${ }^{32}$

At a different period in his life, Lewis associated God with ecclesiastics, with rigoristic morality, which divides everything into black and white. Then God was the 'Cosmic Sadist', the supreme mentor who decides who will be happy and who will suffer: a god who is just waiting to hit the most vulnerable place. Such an image of God is not Christian, it is an image of a fictional deity. However, it is important for us to note the same pattern as in the thoughts of Camus: if I suffer unjustly, the God-Father is not loving.

\section{The Purpose of Godforsakenness: To Reconcile With the Immensity of God and Human Limitations}

The post-war period was a challenge for both Lewis and Camus: how to speak in ordinary language about the pain of mass murder in crematoria and how to explain why the world had become a torture chamber. Camus and Lewis understood that there was a demand for the restoration of sacredness in human relations. And although each chose his own path and form, the goal unites them. They have become a personification of post-Christian thinking, which understands the religious significance of atheism as an attempt to deny and shatter everyday religiosity and simplified theology that does not respond to the demand of a ruined society. Camus and Lewis tried to destroy the image of a false god who tortures people for fun with free will and turns a blind eye to the suffering of the innocent. In this sense, Camus and Lewis were post-Christians trying to form their own apophatic theology that protects the Mystery of God.

C. S. Lewis understood the request of the atheistic world and had the courage to say that if previous generations treated God as a judge, then in the twentieth century God is on the dock and man himself plays the role of prosecutor, judge, and executioner. As heirs of such a world, we are still waiting for a sentence for God, but, in general, God has become so unnecessary that he is not even worthy of judgment. The post-war period also seemed difficult for Lewis; he was tired of apologetics, publicity, and lectures, because none of the truths of the faith could be defended in public debate. ${ }^{33}$ The crisis forced Lewis to seek a new way of writing, and it became myth and symbol, namely, the art world of The Chronicles of Narnia, the Space Trilogy, and Till We Have Faces that became the means by which

30 Cf. Elisabeth KÜBLER-ROSS, On death and dying, Scribner, 1969.

31 Cf. Alister MCGRATH, C. S. Lewis - A Life: Eccentric Genius, Reluctant Prophet, pp. 342-343.

32 LEWIS, The Problem..., p. 11.

33 Cf. LEWIS and CALABRIA, Letters..., p. 98. 
Lewis conveys the same philosophical and theological ideas he embodied in apologetics.

Lewis's mythology is one of the ways of living the transcendent, the eternal, and the divine, it is thinking and language that allows sharing faith without evidence, but through experience. Lewis was convinced that in order to become a true Christian, one should not be ashamed of mythical enlightenment based on theology. Likewise, worries about 'pagan's Christ' should not be rejected as their absence would be more dangerous. In addition, Lewis insists that God himself becomes mythopoetic, and therefore we should be like him. ${ }^{34} \mathrm{He}$ also providentially understood that the basis for dialogue with the Other could be mythology as a path to a concrete experience when abstraction becomes reality and God becomes man.

Myth has enabled Lewis to move from cataphatic to apophatic theology when he understands faith more existentially than rationally, and reason itself becomes a tool to try to delineate what cannot really be delineated. ${ }^{35}$ For Lewis, his faith had always been an act of choice, but now that choice no longer required proof, only evidence. His book, Letters to Malcolm: Chiefly on Prayer, also confirms this as in it he asks many questions but gives not so many answers. Instead, he calls himself 'Job's comforter', who is unable to comfort anyone. ${ }^{36}$ Thus, the darkness of Godforsakenness, sorrow, and loss becomes a sacred space for Lewis, where he, like Moses, can only be silent and contemplate 'for the place where you are standing is holy ground' (Ex 3:5). The crisis of faith begins when God becomes too human and man too divine. A meeting of belief and unbelief starts at the crossroads of the realisation of the inability to know God fully. Experiences of the silence of God and Godforsakenness are about forcing oneself to reject one's own universality (admit one's own superficiality) of knowledge of God. They make people speak of their own authentic experiences, even if they are the experiences of not knowing God or misunderstanding all that $\mathrm{He}$ offers, and even at the extreme, the denying of His existence, as Lewis did a few times.

Camus's new form of understanding of the human soul becomes a confession. His texts The Fall, The First Man, Exile and the Kingdom, and even the philosophical essay The Rebel are united by a single thread - repentance. In the context of understanding the post-war period, special attention should be paid to the novel The Fall, which he had a double motive to write. On the one hand, it is a life of personal repentance before the war and a personal conflict with Sartre and Beauvoir. On the other hand, The Fall is a demand for the metaphysical renewal of all mankind and a rethinking of its faith in God after the calamities of the twentieth century. ${ }^{37}$

Camus often turned to biblical images, but after his personal crisis, this is especially characteristic of his work. The Fall is a novel-confession about the fall of the 'judge-penitent' Jean-Baptiste Clamence. Camus gradually shifts the focus of his questions from the problem of suffering and God to the problem of human freedom. If in The Stranger the loud hero opposes the absurd world, although he slowly becomes a part of it, in The Plague Dr Rie and all the inhabitants of Oran fight the unknown bacillus of plague. Then, in The Fall Camus finally, like Lewis, begins to see the real cause of suffering in the world - human sin. Not amorphous, but a real sin of indifference, pride, vanity, envy, lies, lust, thirst, and anger.

Camus chose Amsterdam for the events in the novel, he himself saying that this city, which is covered with river canals, resembles the circles of hell. The Fall is a novel from the very bottom of hell, in which the soul of the protagonist Jean-Baptiste Clamence is John the Baptist, the 'voice of one calling' (cf. Is 40:3). The whole novel is written in the first person and it is the confession of

34 C. S. LEWIS, Myth Became Fact, New York: Inspirational Press 1996, 343.

35 Cf. Kallistos WARE, C. S. Lewis: An 'Anonymous Orthodox'?, Sobornost 2/1995, pp. 9-27.

36 C. S. LEWIS, Letters to Malcolm: chiefly on prayer, New York, Harcourt, Brace \& World, 1964, pp. 44-45.

37 Olivier TODD, Albert Camus: a life New York: Carroll \& Graf Publishers 2000, p. 341. 
Jean-Baptiste Clamence. He is the embodiment of a faithful God who adheres to the entire Old Testament Decalogue. He is a lawyer, a defender of widows and orphans, and he does not take bribes and does not take payments from the poor. This continued until he witnessed the suicide of a young woman. Fleeing from the voice of her laughter, he found himself in Amsterdam but he had no peace. He wants to be tried, so he deceitfully lures out Jan van Eyck's stolen painting The Just Judges, which was part of the iconostasis. He asks at least one of his interlocutors to become a policeman and cut off his head: 'Above the gathered crowd, you would hold up my still warm head, so that they could recognize themselves in it and I could again dominate-an exemplar. All would be consummated; I should have brought to a close, unseen and unknown, my career as a false prophet crying in the wilderness and refusing to come forth. ${ }^{38}$

Although Camus refers to John's call to be baptised: 'Prepare the way for the Lord, make straight paths for him' (Matt 3:2), in fact, his image is far from that of John the Baptist, for he intended to pave the way for the gospel of Christ, and Camus for the cynical conclusion of the novel. He only wanted to tell his story, which, although reminiscent of confession, has no repentant character.

Concerning metaphysical renewal, Camus agreed that the problem of suffering and murder of the innocent stems not from the problem of the existence/non-existence of God, but from the existence of man himself and his free will. Camus, like Kohelet, underlines the hastily crafted theological answers and rebukes all, especially Christians, who judge and condemn all around in the name of God:

In the name of the Lord, here is what you deserve. Lord? He, my friend, didn't expect so much. He simply wanted to be loved, nothing more. Of course, there are those who love him, even among Christians. But they are not numerous (...) And then he left forever, leaving them to judge and condemn, with pardon on their lips and the sentence in their hearts. ${ }^{39}$

At the end of the novel, it becomes known that his confession to himself is reminiscent of the story of Job, who requires the coming of God to clarify Job's suffering. The difference is that Jean-Baptiste Clamence is not ready to meet God; his last desire for a second chance to change his life is more of a mockery of himself because he knows that by his own power he is not able to change: 'O young woman, throw yourself into the water again so that I may a second time have the chance of saving both of us! It's too late now. It will always be too late. Fortunately!'40

Camus, as with Lewis, wanted to debunk the mask of decency that is on the faces of the righteous, but which in essence are not righteous and turn a blind eye to the murder of the innocent. It is the court of the world, which condemned millions of people to suffer in concentration camps. The Fall not only informs about nihilism, but also about the world and human dead souls who do not know how to love and suffer from it: souls, thirsty for faith and incapable of it.

This recalls apophatic thinking about God: the more you believe, the less you understand and thus the more you believe. It is an opportunity to know God as He reveals Himself to us. It is an endless journey. Another reason why this practice is justified in our time - omissible of understanding God is that if God becomes so simplified and familiarised to man, He becomes devalued. Apophatic theology would rather say who God is not, than who He is. This practice is necessary for our time, when God becomes too simplified, and devalued, desacralised.

In the prayer of Godforsakenness, 'My God, my God, why have you forsaken me?' (Matt 27:46;

38 Albert CAMUS, The Fall New York: Knopf 1958, pp. 146-147.

39 Ibid., p. 115.

40 Ibid., p. 148. 
Mk 15:34), God's presence is never separated from His absence and vice versa. All of this emphasises the importance of not turning God into the 'God of my imagination', but instead constantly looking for His true face to say, as Job, 'My ears had heard of you but now my eyes have seen you' (Job 42:5).

\section{Conclusions}

Lewis and Camus can be considered as apostles of 'healthy scepticism'. They were disappointed with the principles of modern Christianity and tried to overcome this crisis. Both thinkers enhance the 'space of unbelief' and the desperate search for God. At the same time, there are many paradoxes in their ideas: Camus rejects God but is constantly seeking a guarantor of morality as a supporter who can interfere in the world order; Lewis is also experiencing his own crises related to the image of God, while defending God, then accusing Him. This, above all, speaks of their living need to seek the truth, ask, deny, and sometimes even destroy their own previous stages of faith.

Albert Camus and C. S. Lewis tried to show the drama of the relationship between man and God when belief and unbelief are not unambiguous categories, but the way to God. Albert Camus and C. S. Lewis affirm that both theology and philosophy have more questions than answers when they try to understand the experience of Godforsakenness. And any unambiguity about belief and unbelief is a way of separating and marginalising some people from others. Godforsakenness in Christian theology is the experience of the hidden God, which is expressed in the experience of being with the God that is 'present and absent' at the same time, and as a result, it can be the cause of unbelief. On the one hand, it can be a complete rejection of God, and on the other hand, it can be a way to cleanse God's Image from the shell of inanimate formalities and schemes, dead traditions, and primitive theology. In this case Christian unbelief sometimes is a necessity.

However, the most difficult challenge which is revealed by Camus and Lewis facing modern theology is whether it will be able to release God to nonbelievers? Will post-Christianity be able to jump over the secular line that separates God from man and have the courage to talk about the Incarnate Christ? Camus's and Lewis's experience confirms that this is possible if Christians are persuaded to doubt that they have fully recognised God. It may be a call to postmodern man if he dares to reject contemporary religious nihilism and simplification and will seek a new meaning of life, which can open a way to a living faith in the living God.

\section{Contact}

\section{Yuliia Vintoniv MA}

Ukrainian Catholic University

Faculty of Philosophy and Theology

Department of Pastoral Theology

Khutorivka 35a, Lviv, 79070

vintonivyu@ucu.edu.ua 